\title{
Good hygienic practices and identification of contamination sources in Hotel Food and Beverage sector
}

\author{
Aline de Oliveira RODRIGUES ${ }^{1}$, Eliezer Avila GANDRA ${ }^{1}$, Rita de Cássia dos Santos da CONCEIÇÃO ${ }^{1}$, \\ Débora Rodrigues SILVEIRA ${ }^{1}$, Cláudio Dias TIMM ${ }^{1 *}$
}

\begin{abstract}
This study aimed to evaluate the application of good practices in hotel restaurants in Southern Brazil, relate these practices to the microbiological quality of the food offered, in addition to identifying contamination sources. The food and beverage sector of four hotels was evaluated by means of a checklist based on the Resolution 216/2014 of Agência Nacional de Vigilância Sanitária and microbiological analyzes. Surface, utensil, equipment and handlers' hand samples were collected for coagulase positive Staphylococcus and thermotolerant coliform count. Isolates obtained from these culture counts were compared by band profiles obtained by rep-PCR. According to non-conformities observed, only one hotel was rated as excellent in good practices avaliation. Some microbiological analysis exceeded the allowed limit for the analyzed microorganism count, revealing failure in the hygiene-sanitary process. Genetic similarities between some food samples and handlers' hands and utensils were identified. These results showed inadequacies in the process of food care and handling which may compromise the quality of food offered to custumers.
\end{abstract}

Keywords: food safety; coagulase positive Staphylococcus; thermotolerant coliform; rep-PCR.

Practical Application: The good hygienic practices evaluation by checklists does not correspond to food microbiological quality.

\section{Introduction}

The industry of tourism has been expanding worldwide, and together with this expansion, there is also the development of the hotel industry, which offers many services, among which food and beverages (F\&B). The implementation of good hygienic practices (GHP) is required to control the food quality and to ensure that the customers are not exposed to any food-related risks. These practices consist of a set of procedures aimed to attain specific identity and quality standards of products and/or services in the food industry, including materials and utensils these products may get in contact with (Akutsu et al., 2005). The GHP are mandatory standards for all industries and food-producing businesses by Brazilian law (Brasil, 1993, 1997, 2004).

Bacteria of the genus Staphylococcus are widely distributed microorganisms which are usually found on the skin and mucous membranes of humans and other mammals (Neves et al., 2007). Among these, Staphylococcus aureus is the species which is most often related to cases and outbreaks of food poisoning due to its ability to produce enterotoxins (Silva et al., 2001). In addition to S. aureus, S. hyicus and S. intermedius have also been associated to foodborne disease outbreaks. These are the three most relevant species in food microbiology from this genus (Franco \& Landgraf, 2003). The presence of thermotolerant coliforms in food signals to post-processing contamination, which is generally caused by lack of hand hygiene by handlers. Bacterium Escherichia coli is the main thermotolerant coliform found in the intestinal tract of humans, and some strains are pathogenic to human being (Campos et al., 2009).
Molecular methods for the detection of pathogenic bacteria in foods are presently being employed as quicker and more effective tools for microorganism differentiation and identification. The development of the amplification technique by the Polymerase Chain Reaction (PCR) has enabled the use of specific sequences of microbial genome as genetic markers of genus, species, and subspecies, and can be a viable option to the traditionally used morphologic and biochemical methods (Malorny et al., 2003).

Various PCR modifications have been described, among which Rep-PCR, which involves the amplification of areas between repetitive elements, generating specific profiles (Gandra et al., 2008). This technique allows the determination of the origins of pathogenic microorganisms' contamination in food catering services such as those of hotels, thus filling the gap caused by the lack of information in this field of activity.

The aim of this study was to evaluate the application of good practices to food \& beverage sector in microbiological quality control of food handled and consumed in these places, and the identification of possible contamination sources.

\section{Materials and methods}

\subsection{Hotel food \& beverage sector}

F\&B sectors of four hotels identified as hotel 1, 2, 3 and 4, located in central areas of the cities of Rio Grande and Pelotas, Rio Grande do Sul State, were evaluated as to hygiene and 
sanitary conditions in two visits with a minimum 30 days interval between visits, by means of the application of a checklist and microbiological analysis of samples collected at these sites.

\subsection{Good practices evaluation}

A good practices checklist adapted into a questionnaire on food services was created according to recommended procedures by Resolution 216/2004 of ANVISA (Brasil, 2004), which includes the following items: identification of the business, buildings and facilities (internal and external premises), equipment, furniture and utensils sanitation, pest control, water supply, waste management, food handlers, raw materials, food preparation, food transport, consumption exposure, records and liabilities. All items were assessed by direct observation during two visits by the same observer.

The classification of each business establishment was based on scoring criteria established by Resolution 275/2002 of ANVISA (Brasil, 2002): excellent (0-25\% non-compliances), good (25-50\% non-compliances) and bad (> 50\% non-compliances).

\subsection{Sample collection}

Five samples of approximately $200 \mathrm{~g}$ breakfast food, especially dairy foods such as ricotta cheese, Prato cheese, dairy drink, dulce de leche, butter, Colonial cheese, cream, hot milk, milk shake and cream chesse, and other foods such as fruit salad, honey and ham, which generally provide favorable environments for the multiplication of bacteria of the genus Staphylococcus and thermotolerant coliforms, were collected from each business establishment at each visit. The samples were collected by using sterile utensils and were packed in sterile plastic bags.

To evaluate food handler hygiene, samples from the hands of two handlers (one from their right and another from their left hand) were collected by using sterile swabs lightly moistened in $0.1 \%$ sterile peptone water, according to American Public Health Association (2001) recommendations. The swab was rubbed in rotary motion from the bottom of the right palm to the tip of the fingers; this procedure was repeated three times towards each finger. The swab was also moved back and forth on one hand side from the wrist line up to between the fingers and finally on the other side of the hand up to the wrist.

To evaluate surfaces and equipment, counter samples where food was handled (1 sample), cutting boards (one sample) and food slicer (1 sample) were collected with swabs moistened in sterile $0.1 \%$ peptone water which were rubbed in a $100 \mathrm{~cm}^{2}$ area delimited by sterilized stainless-steel templates. The work surface sampling area was delimited centrally. The food slicer sampling area was its cutting blade. The swabs were put into tubes containing $10 \mathrm{~mL} 0.1 \%$ sterile peptone water. The total material collected consisted of 12 samples from each food establishment. The material was stored in isothermal containers with ice and immediately sent to laboratory for analysis.

\subsection{Bacterial quantification}

Samples were analyzed by quantification of coagulase-positive Staphylococcus (CPS) and thermotolerant coliforms, according to Brasil (2003). For CPS count, serial dilutions of $1 \mathrm{~mL}$ samples were plated in duplicate on Baird-Parker agar (Himedia, Mumbai, India) and incubated at $37^{\circ} \mathrm{C}$ for $48 \mathrm{~h}$. Five atypical and five typical colonies from each plate were inoculated in Brain Heart Infusion (BHI, Himedia) and incubated at $37^{\circ} \mathrm{C}$ for 24 hours to perform the coagulase test, which consisted of mixing $0.3 \mathrm{~mL}$ of each culture with $0.3 \mathrm{~mL}$ rabbit plasma incubated at $37^{\circ} \mathrm{C}$ for 6 hours to observe clotting. The proportion of coagulase-positive colonies in relation to the count of typical and atypical colony counts on the plate was calculated, and the final count result for each plate was obtained by adding the number of coagulasepositive colonies. Following, the average of duplicates was calculated and the correction of the dilution used for the count was performed.

The thermotolerant coliforms count was performed by the Most Probable Number (MPN) technique. One microliter of each dilution was inoculated in a series of three test tubes with an inverted Durham tube inside containing sodium Lauryl sulfate broth (Isofar, Rio de Janeiro, Brazil). After incubation at $37^{\circ} \mathrm{C}$ for $48 \mathrm{~h}$, presumptive coliform growth was found, signaled by the formation of gas inside the Durham tubes. For confirmatory thermotolerant coliform analysis, inoculation by transferring a sample aliquot from the positive tubes in the previous stage into test tubes with Durham tubes containing EC broth (Acumedia, Michigan, USA) and incubation at $45^{\circ} \mathrm{C}$ for $48 \mathrm{~h}$ were performed. Then, gas production was observed in each tube and the result was obtained by an MPN Specific Table.

\subsection{Isolate obtain}

Three CPS colonies obtained from count plates were inoculated in $\mathrm{BHI}$ and incubated at $37^{\circ} \mathrm{C}$ for $24 \mathrm{~h}$. An aliquot from thermotolerant coliform cultures characterized by gas production in EC broth was seeded by the exhaustion technique in MacConkey agar. After incubation at $37^{\circ} \mathrm{C}$ for $24 \mathrm{~h}$, three lactose positive and three lactose negative colonies were plated on $\mathrm{BHI}$ and incubated at $37^{\circ} \mathrm{C}$ for $24 \mathrm{~h}$. BHI cultures were added with $20 \%$ glycerol for stock maintenance at $-18^{\circ} \mathrm{C}$. Isolates were recovered in $\mathrm{BHI}$ at $37^{\circ} \mathrm{C}$ for $24 \mathrm{~h}$ when necessary.

\subsection{Rep-PCR}

The DNA was isolated according Sambrook \& Russel (2001), with modifications. To complete the CPS isolate cell lysis, $100 \mu \mathrm{L}$ lysostaphin solution $(100 \mu \mathrm{g} / \mathrm{mL}$ lysostaphin in $20 \mathrm{mM}$ acetate buffer) was added after pellet obtained by centrifuging the culture in BHI and then it was incubated at $37^{\circ} \mathrm{C}$ for $1 \mathrm{~h}$. The extracted DNA was stored at $-18^{\circ} \mathrm{C}$.

The isolates were analyzed by rep-PCR using the primer (GTG), which has high Staphylococcus spp. (Braem et al., 2011) and thermotolerant coliform discriminatory power (Mohapatra et al., 2007). The rep-PCR conditions were: $2.5 \mu \mathrm{L}$ DNA, $2 \mu$ L oligonucleotide 5'-GTGGTGGTGGTGGTG-3', $12.5 \mu \mathrm{L}$ Master Mix (Quiagem, Germany) and $8 \mu \mathrm{L}$ water to complete the reaction volume. Amplification cycles were performed as follows: 1 cycle at $94^{\circ} \mathrm{C}$ for 5 minutes, 30 subsequent cycles at $95^{\circ} \mathrm{C}$ for $30 \mathrm{~s}, 45^{\circ} \mathrm{C}$ for $1 \mathrm{~min}$ and $60^{\circ} \mathrm{C}$ for $5 \mathrm{~min} /$, and finally $1 \mathrm{cycle}$ at $60^{\circ} \mathrm{C}$ for $16 \mathrm{~min}$. To visualize the band patterns of the different amplified regions in the genome, PCR products were 
stained with GelRed and electrophoresis was performed in 2\% agarose gel (Versalovic et al., 1994).

The study was approved by the Ethics Committee of the Federal University of Pelotas (Universidade Federal de Pelotas, Pelotas, Brazil) under number 710.766 .

\section{Results and discussion}

According to the data obtained in the evaluation of checklist items which identified the percentage of non-conformities (NC) in the F\&B sector to the evaluated hotels, hotel 1 was classified as excellent, hotels 3 and 4 as good and hotel 2 as bad in the first visit and as good in the second, as shown in Table 1. It was found that the four hotels evaluated showed a high inadequacy percentage as to the raw material item, and the greatest shortcomings found were lack of a specific area for the reception of foods, the absence of product inspection upon delivery and improper storage, as many foods were not kept on appropriate shelves, and the minimum space between products, floor and wall $(10 \mathrm{~cm})$, according to Resolution 216/2014 of ANVISA (Brasil, 2004), was not observed. Moreover, not all shelves were made of smooth and impermeable material.

The building item showed high inadequacy rates for hotels 2 and 4 . According to Silva (2008), the physical planning phase of a restaurant should be performed by a multidisciplinary team with the guidance of a food service management expert, considering the organization, flows and techniques to be adopted by the food service unit.

Only hotel 2 showed irregularities in integrated pest control because there was no effective and continuous action to keep the facility free of vectors and pests whatsoever. Such irregularities have also been observed by Ferraz (2010), who evaluated 15 commercial restaurants in the city of São Paulo and found that 10 had no pest control records.
The hotel 2 also showed high handler inadequacy, as there was no proper hand hygiene frequency, handlers did not have short nails and wore adornments; in addition, there were no records of regular training on hygiene and food handling. High inadequacy handler percentages have also been found by Serafim (2010) upon good practices evaluation of 12 hotels in the city of Porto Alegre/RS by means of a checklist; 10 of the hotels analyzed by the author were rated unsatisfactory for this item.

In good practices evaluation there was a high percentage of inadequacy as to the raw material item at the first visit to the four hotels. Zambiazi \& Martins (2010) mentioned absence of control upon raw material delivery in $70 \%$ of 10 commercial restaurants evaluated in the city of Cascavel, Paraná State, which suggests that hotel F\&B sectors show some of the same shortcomings as commercial restaurants.

Food preparation steps were not in agreement with legislation in hotels 2, 3 and 4, which showed high inadequacy percentages. Main shortcomings found were risk of cross-contamination, the absence of food temperature check, inadequate labeling of prepared foods and improper produce hygiene. This problem has also been mentioned by Serafim (2010) who, after evaluating produce sanitization procedures in hotel restaurants, found that $100 \%$ of the facilities were inadequate, and that $42 \%$ of hotels did not even have specific products for the disinfection of these food items, which was also observed in hotel 2 in this study.

The hotels 1 and 4 had technicians responsible for the F\&B sector. On the other hand, the hotels 2 and 3 did not have any qualified technicians for this job. This highlights the failure by the establishment management and competent regulatory agency to enforce legislation provisions.

As for documentation, record and accountability items, only the hotel 1 had a good practices and standard operating procedure (SOP) manual; however, some of the recommendations in the manual were not followed.

Table 1. Percentage of inadequacy to the food and beverage sector in hotels in the cities of Rio Grande and Pelotas, RS by evaluated blocks.

\begin{tabular}{|c|c|c|c|c|c|c|c|c|c|c|c|c|c|c|c|c|c|}
\hline \multirow{4}{*}{ Blocks of checklist ${ }^{\mathrm{a}}$} & \multirow{4}{*}{$\begin{array}{c}\text { Total } \\
\text { of } \\
\text { items }\end{array}$} & \multicolumn{16}{|c|}{ Non compliances } \\
\hline & & \multicolumn{4}{|c|}{ Hotel 1} & \multicolumn{4}{|c|}{ Hotel 2} & \multicolumn{4}{|c|}{ Hotel 3} & \multicolumn{4}{|c|}{ Hotel 4} \\
\hline & & \multicolumn{2}{|c|}{ Collect 1} & \multicolumn{2}{|c|}{ Collect 2} & \multicolumn{2}{|c|}{ Collect 1} & \multicolumn{2}{|c|}{ Collect 2} & \multicolumn{2}{|c|}{ Collect 1} & \multicolumn{2}{|c|}{ Collect 2} & \multicolumn{2}{|c|}{ Collect 1} & \multicolumn{2}{|c|}{ Collect 2} \\
\hline & & $\mathrm{n}^{\mathrm{ob}}$ & $\%$ & $\mathrm{n}^{\circ}$ & $\%$ & $\mathrm{n}^{\circ}$ & $\%$ & $\mathrm{n}^{\mathrm{o}}$ & $\%$ & $\mathrm{n}^{\mathrm{o}}$ & $\%$ & $\mathrm{n}^{\circ}$ & $\%$ & $\mathrm{n}^{\mathrm{o}}$ & $\%$ & $\mathrm{n}^{\mathrm{o}}$ & $\%$ \\
\hline 1. Buildings & 31 & 5 & 16.1 & 4 & 12.9 & 20 & 64.5 & 15 & 48.4 & 9 & 29 & 9 & 29 & 16 & 51.6 & 6 & 19.3 \\
\hline 2. Sanitation & 8 & 2 & 25 & 2 & 25 & 2 & 25 & 1 & 12.5 & 2 & 25 & 1 & 12.5 & 2 & 25 & 2 & 25 \\
\hline 3. Pest control & 3 & 0 & 0 & 0 & 0 & 3 & 100 & 1 & 33.3 & 0 & 0 & 0 & 0 & 0 & 0 & 0 & 0 \\
\hline 6. Food handlers & 11 & 4 & 36.4 & 1 & 9.1 & 7 & 63.6 & 7 & 63.6 & 4 & 36.4 & 4 & 36.4 & 5 & 45.4 & 5 & 45.4 \\
\hline 7. Raw materials & 5 & 2 & 40 & 2 & 40 & 2 & 40.0 & 3 & 60 & 3 & 60 & 2 & 40 & 3 & 60 & 2 & 40 \\
\hline 8. Food preparation & 14 & 3 & 21.4 & 3 & 21.4 & 7 & 50.0 & 8 & 57.1 & 7 & 50 & 5 & 35.7 & 8 & 57.1 & 8 & 57.1 \\
\hline $\begin{array}{l}\text { 10. Consumption } \\
\text { exposure }\end{array}$ & 7 & 1 & 14.3 & 1 & 14.3 & 3 & 42.9 & 3 & 42.9 & 1 & 14.3 & 1 & 14.3 & 3 & 42.9 & 2 & 28.6 \\
\hline
\end{tabular}

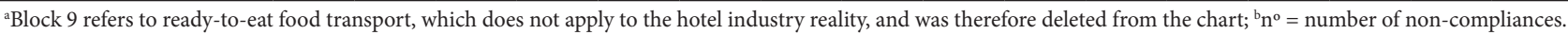


At the second visit to the hotels, some modifications in good practices procedures could be observed. While hotels 1 , 3 and 4 maintained the same classification as to the number of non-compliances found, hotel 2 changed from bad to good. This business establishment had been notified by the municipality regulatory agency, prior to our first visit, that adjustments such as the installation of door and window millimeter screens, the use of non-manually operated waste collectors with lids, and the replacement of wooden handled utensils by polyethylene handled ones, had to be made. These adaptations had been made and verified upon our second good practices check, thus improving the hotel rating. Despite all the improvements in hotel 2, however, the handlers item maintained a high inadequacy percentage.

Based on the considerations above, the development of an awareness of the supervisors of this sector in relation to good handling practices by providing continuous training to food handlers and promoting higher investments in physical structure improvement, thus ensuring a product which meets acceptable standards of hygiene and sanitation, is essential. Carrijo et al. (2010) highlight the importance of constant training and daily monitoring of good practices in food handling to avoid many of the mistakes that are often committed by misinformation and/or lack of supervision.

The hotel 1 exceeded CPS limits allowed by current law (Brasil, 2001) for certain foods, thus exposing the consumer to food poisoning risk, once CPS can produce thermoresistant enterotoxins when its population exceeds $10^{5} \mathrm{UFC} / \mathrm{g}$ food (Jay, 2001). This hotel also showed a high thermoresistant coliform count (Table 2). These results demonstrated that hotel 1, despite being classified as excellent, did not offer consumer products under appropriate sanitation and hygiene conditions as recommended by good practices, pointing to inadequacies in the inspection process and production monitoring.

The hot milk contamination found in hotel 2 suggests that there were flaws in the cleaning process of utensils used for product storage during distribution, inasmuch as Staphylococcus should have been eliminated during milk heat treatment. The presence of thermotolerant coliforms in cheese from hotel 3 suggests the use of low-quality raw materials, inadequate processing conditions, poor hygiene practices by handlers, or inadequate storage and transportation. Comparable results were also found by Ferreira et al. (2011) upon analyzing 20 samples of minas frescal cheese obtained from street markets in the city of Uberlândia, Brazil. The authors found that $80 \%$ of the samples were above legal acceptable thermotolerant coliform count limits.

The hotel 3 maintained its classification as good in the good practices check; however, a greater number of inadequate food items were identified at this collection. The second collection from this hotel showed higher food inadequacy, which can be explained by the fact that the staff of the F\&B sector had been totally replaced. According to Serafim (2010), most hotel restaurants only promote handlers' training after a trial period due to the constant change of workers in this sector, which may compromise the handlers' correct procedures as well as other handling processes because of the unfamiliarity of the new team.

The handlers' hands analysis showed values above those allowed by the American Public Health Association (2001) for hotels 3 and 4 at the second collection (Table 3 ), revealing misapplication or absence of hand hygiene, which can cause food contamination. Similar results have been described by Coelho et al. (2010), who found samples with $1,0 \times 10^{6} \mathrm{CFU} /$ hand values after evaluating commercial restaurant handlers in the

Table 2. Results of microbiological analysis for coagulase positive Staphylococcus and thermotolerant food count in hotels in the cities of Rio Grande and Pelotas/RS in 2014.

\begin{tabular}{|c|c|c|c|c|c|c|c|c|c|c|c|c|c|c|c|c|c|c|}
\hline \multirow{3}{*}{ Sample } & \multicolumn{4}{|c|}{ Hotel 1} & \multicolumn{4}{|c|}{ Hotel 2} & \multicolumn{4}{|c|}{ Hotel 3} & \multicolumn{4}{|c|}{ Hotel 4} & \multicolumn{2}{|c|}{ Microbiological limits ${ }^{\mathrm{a}}$} \\
\hline & \multicolumn{2}{|c|}{ Collect 1} & \multicolumn{2}{|c|}{ Collect 2} & \multicolumn{2}{|c|}{ Collect 1} & \multicolumn{2}{|c|}{ Collect 2} & \multicolumn{2}{|c|}{ Collect 1} & \multicolumn{2}{|c|}{ Collect 2} & \multicolumn{2}{|c|}{ Collect 1} & \multicolumn{2}{|c|}{ Collect 2} & \multirow{2}{*}{$\begin{array}{c}\text { CPS } \\
\text { (CFU/g or mL) }\end{array}$} & \multirow{2}{*}{$\begin{array}{c}\text { TC } \\
\text { (MPN/g or mL) }\end{array}$} \\
\hline & CPS & TC & $\overline{\mathrm{CPS}}$ & TC & CPS & TC & CPS & TC & $\overline{\mathrm{CPS}}$ & TC & $\overline{\mathrm{CPS}}$ & TC & $\overline{\mathrm{CPS}}$ & $\mathrm{TC}$ & $\overline{\mathrm{CPS}}$ & TC & & \\
\hline $\begin{array}{l}\text { Ricotta } \\
\text { cheese }\end{array}$ & $\mathrm{A}$ & $\mathrm{U}$ & $\mathrm{A}$ & $\mathrm{A}$ & - & - & - & - & - & - & - & - & - & - & - & - & $1.0 \times 10^{3}$ & $5.0 \times 10^{3}$ \\
\hline Prato cheese & $\mathrm{U}$ & $\mathrm{U}$ & $\mathrm{A}$ & $\mathrm{A}$ & $\mathrm{U}$ & A & A & $\mathrm{A}$ & A & A & $\mathrm{U}$ & A & A & $\mathrm{A}$ & A & A & $1.0 \times 10^{3}$ & $1.0 \times 10^{3}$ \\
\hline Dairy drink & A & A & A & A & - & - & - & - & - & - & - & - & A & A & A & A & $5.0 \times 10^{2}$ & $1.0 \times 10^{1}$ \\
\hline $\begin{array}{l}\text { Dulce de } \\
\text { leche }\end{array}$ & $\mathrm{U}$ & $\mathrm{U}$ & A & A & - & - & - & - & - & - & - & - & - & - & - & - & $1.0 \times 10^{2}$ & $5.0 \times 10^{1}$ \\
\hline Fruit salad & $\mathrm{U}$ & $\mathrm{U}$ & A & A & - & - & - & - & - & - & - & - & - & - & - & - & $1.0 \times 10^{3}$ & $5.0 \times 10^{2}$ \\
\hline Honey & - & - & - & - & A & A & A & A & - & - & - & - & - & - & - & - & - & $1.0 \times 10^{2}$ \\
\hline Ham & - & - & - & - & U & A & A & A & - & - & - & - & - & - & - & - & $5.0 \times 10^{3}$ & $1.0 \times 10^{5}$ \\
\hline Butter & - & - & - & - & A & A & A & A & A & A & $\mathrm{U}$ & A & - & - & - & - & $1.0 \times 10^{2}$ & $1.0 \times 10^{1}$ \\
\hline $\begin{array}{l}\text { Colonial } \\
\text { cheese }\end{array}$ & - & - & - & - & - & - & - & - & $\mathrm{U}$ & $\mathrm{U}$ & $\mathrm{U}$ & A & - & - & - & - & $1.0 \times 10^{3}$ & $1.0 \times 10^{3}$ \\
\hline Cream & - & - & - & - & - & - & - & - & A & A & A & A & - & - & - & - & $1.0 \times 10^{2}$ & $1.0 \times 10^{1}$ \\
\hline Hot milk & - & - & - & - & $\mathrm{U}$ & A & A & A & A & A & A & A & A & A & A & A & Abs. & Abs. \\
\hline Milk shake & - & - & - & - & - & - & - & - & - & - & - & - & A & A & A & A & $5.0 \times 10^{2}$ & $1.0 \times 10^{1}$ \\
\hline $\begin{array}{l}\text { Cream } \\
\text { chesse }\end{array}$ & - & - & - & - & - & - & - & - & - & - & - & - & A & A & A & A & $1.0 \times 10^{3}$ & $1.0 \times 10^{1}$ \\
\hline
\end{tabular}

${ }^{a}$ Microbiological limits as established by Resolution 12/2001 of ANVISA (Brasil, 2001); CPS - coagulase positive Staphylococcus; TC - thermotolerant coliforms; A - acceptable microbiological limits; U - unacceptable microbiological limits; CFU - colony forming unit; MPN - Most Probable Number; Abs. - Absence. 
Table 3. Results of microbiological coagulase positive Staphylococcus and thermotolerant coliform count from handlers' hands, equipment and utensils analyzed in hotels in the cities of Rio Grande and Pelotas/RS, in 2014.

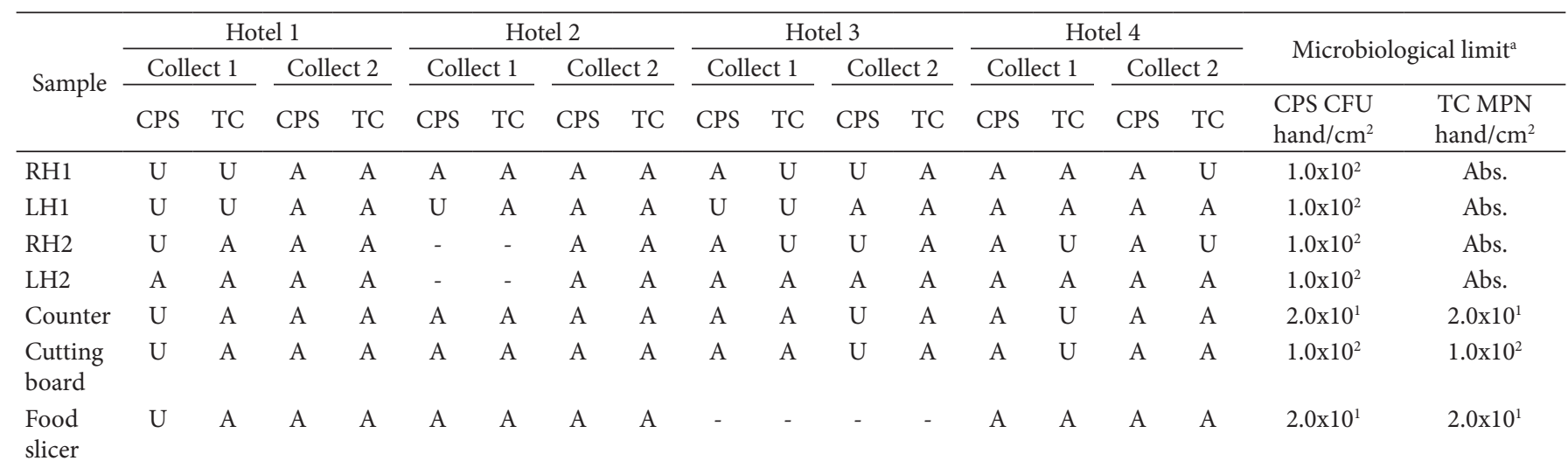

${ }^{a}$ Microbiological limits as established by American Public Health Association (2001); CPS - coagulase positive Staphylococcus; TC - thermotolerant coliforms; A - acceptable microbiological limits; U - unacceptable microbiological limit; CFU - colony forming unit; MPN - Most Probable Number; RH1 - right hand handler 1; LH1 - left hand handler 1; RH2 - right hand handler 2; LH2 - left hand handler 2; Abs - Absence.

city of Viçosa, MG. The acceptable handlers' hands examination values at the collection from hotels 1 and 2 may be attributed to the improvement of good practices control and monitoring, as reported by the qualified technician from 1 hotel, who claimed to have intensified correct hand hygiene control through appropriate antibacterial agent use.

The contamination found in some utensils and equipment may evidence the inefficiency of cleaning and disinfection processes of tools and equipment that have direct contact with food, which may cause cross-contamination. Similar results have been found by Kochanski et al. (2009), who collected samples of equipment and utensils from a food and nutrition unit in the north of the Rio Grande do Sul State, Brazil, and found that all countertop, manual processor and cutting board samples, thought to have been sanitized by handlers, were not within acceptable limits for mesophilic aerobic microorganisms, probably due to the lack of a standard operational procedures, considering that these microorganisms can be removed by conventional cleaning and sanitation processes.

The genetic similarity between CPS isolates and thermotolerant coliforms was analyzed by subtyping products obtained by the rep-PCR technique. The profiles of CPS isolate bands from the first collection in hotel 1 for Prato cheese and the cutting board were indistinguishable from each other, which means cross-contamination between them. Profiles of bands obtained from CPS isolates from homemade cheese and the right hand of two evaluated handlers at the second collection from hotel 3 were also classified as indistinguishable, demonstrating failure in handlers' procedures upon food manipulation. Genetic similarity between cutting board and butter band profiles was found for this same hotel, showing the improper cleaning and disinfection of this utensil, which has direct contact with food and can be an important source of pathogenic microorganism dispersion. According to Aguiar et al. (2006), cutting boards should be regularly replaced as excessive cuts can store microorganisms that adhere to the contact surface, compromising the material. In our study, all cutting boards examined were made of polyethylene, except for hotel 2 which had glass cutting boards and it was contamination-free.

In the genetic similarity analysis of thermotolerant coliform isolates, indistinguishable band profiles were only found for fruit salad and handlers' hands at hotel 1 collection 1 . The handler was identified as a potential contamination agent, thus reinforcing the need to adopt proper hygiene practices during food processing. This problem was also discussed by Chavapal et al. (2006), who used the rep-PCR technique to assess dairy farm milking hygiene when monitoring the quality of milk. The found milkers' hands to be the main source of contamination.

\section{Conclusions}

Hotel restaurants showed inadequacy or inefficiency in the hygiene and sanitation processes of the assessed items, partially compromising the microbiological quality of food offered to the consumer. The checklist alone is not enough to control hygiene and sanitation procedures to ensure the microbiological quality of food, and procedures to attain this quality must be effectively monitored.

This study also demonstrated the role of handlers as potential causes of food contamination, highlighting the need of regular training and production activity monitoring to minimize potential flaws and ensure service quality. In addition, it was evidenced that the flaws in the process of utensil cleaning and disinfection play an important part in the maintenance of food contamination sources, which could be eliminated by the adoption of standard hygiene measures to provide safe conditions during handling.

\section{References}

Aguiar, C., Pereira, L., Mazzonetto, C., Simony, R. F., Ginefra, I., \& Marçal, T. (2006). Implementação de boas práticas de manipulação em uma creche do município de São Paulo. Revista Cadernos, 12(1), 47-57.

Akutsu, R. C., Botelho, R. A., Camargo, E. B., Sávio, K. E. O., \& Araújo, W. C. (2005). Adequação das boas práticas de fabricação em serviços de alimentação. Revista de Nutrição, 18(3), 419-427. http://dx.doi. org/10.1590/S1415-52732005000300013. 
American Public Health Association - APHA, Committee on Microbiological Methods for Foods. (2001). Compendium of methods for the microbiological examination of foods (4th ed.). Washington: APHA.

Braem, G., De Vliegher, S., Supré, K., Haesebrouck, F., Leroy, F., \& De Vuyst, L. (2011). (GTG) -PCR fingerprinting for the classification and identification of coagulase-negative Staphylococcus species from bovine milk and teat apices: a comparison of type strains and field isolates. Veterinary Microbiology, 147(1-2), 67-74. http://dx.doi. org/10.1016/j.vetmic.2010.05.044. PMid:20599332.

Brasil, Agência Nacional de Vigilância Sanitária. (1993, December 2). Dispõe sobre o controle de qualidade na área de alimentos (Portaria $\mathrm{n}^{\circ} 1428$, de 26 de novembro de 1993). Diário Oficial [da] República Federativa do Brasil.

Brasil, Ministério da Agricultura, Pecuária e Abastecimento. (1997, September 8). Dispõe sobre regulamento técnico das condições Higiênico-Sanitárias e de Boas Práticas de Fabricação para estabelecimentos elaboradores/industrializadores de alimentos (Portaria no 368, de 4 de setembro de 1997). Diário Oficial [da] República Federativa do Brasil.

Brasil, Agência Nacional de Vigilância Sanitária. (2001, January 10). Regulamento técnico sobre padrões microbiológicos para alimentos (Resolução RDC no 12, de 2 de janeiro de 2001). Diário Oficial [da] República Federativa do Brasil.

Brasil, Agência Nacional de Vigilância Sanitária. (2002, October 23). Dispõe sobre regulamente técnico de procedimentos operacionais padronizados aplicados aos estabelecimentos produtores/ industrializadores de alimentos e a lista de verificação de boas práticas de fabricação em estabelecimentos produtores/industrializadores de alimentos (Resolução RDC n 275, de 21 de outubro de 2002). Diário Oficial [da] República Federativa do Brasil.

Brasil, Ministério da Agricultura, Pecuária e Abastecimento. (2003, September 18). Métodos analíticos oficiais para análises microbiológicas para controle de produtos de origem animal e água (Instrução Normativa $n^{\circ}$ 62, de 26 de agosto de 2003). Diário Oficial [da] República Federativa do Brasil.

Brasil, Agência Nacional de Vigilância Sanitária. (2004, September 16). Dispõe sobre regulamento técnico de boas práticas para serviço de alimentação (Resolução RDC n 216, de 15 de setembro de 2004). Diário Oficial [da] República Federativa do Brasil.

Campos, A. K. C., Cardonha, A. M. S., Pinheiro, L. B. G., Ferreira, N. R., Azevedo, P. R. M., \& Stamford, T. L. M. (2009). Assessment of personal hygiene and practices of food handlers in municipal public schools of Natal, Brazil. Food Control, 20(9), 807-810. http://dx.doi. org/10.1016/j.foodcont.2008.10.010.

Carrijo, K. F., Dias, F. S., Pinto, M. S., \& Abreu, D. I. C. (2010). Avaliação das boas práticas e condições higiênicosanitárias na elaboração de alimentos em um restaurante universitário do Rio de Janeiro, RJ. Higiene Alimentar, 24(184-185), 38-41.

Chavapal, L., Moon, D. H., Gomes, J. E., Duarte, F. R., \& Tsai, S. M. (2006). Aplicação da técnica de Rep-PCR no rastreamento de Staphylococcus aureus em salas de ordenha, para o monitoramento da qualidade do leite. Revista Científica de Produção Animal, 43(3), 309-320.
Coelho, A. I. M., Milagres, R. C. R. M., Martins, J. F. L., Azeredo, R. M. C., \& Santana, A. M. C. (2010). Contaminação microbiológica de ambientes e superfícies em restaurantes comerciais. Ciencia \& Saude Coletiva, 15(Suppl. 1), 1597-1606. http://dx.doi.org/10.1590/ S1413-81232010000700071. PMid:20640321.

Ferraz, A. P. C. (2010). Condições higiênico sanitárias de buffets da região do ABC, SP. Higiene Alimentar, 24(184-185), 53-59.

Ferreira, R. M., Spini, J. C. M., Carraza, L. G., Sant'Ana, D. S., Oliveira, M. T., Alves, L. R., \& Carraza, T. G. (2011). Quantificação de coliformes totais e termotolerantes em queijo minas Frescal Artesanal. Pubvet, 5(5), 1022. http://dx.doi.org/10.22256/pubvet.v5n5.1022.

Franco, B. D. G. M., \& Landgraf, M. (2003). Microbiologia dos alimentos. São Paulo: Atheneu.

Gandra, E. A., Gandra, T. K. V., Mello, W. S., \& Godoi, H. S. (2008). Técnicas moleculares aplicadas à microbiologia de alimentos. Acta Scientiarum. Technology, 30(1), 109-118. http://dx.doi.org/10.4025/ actascitechnol.v30i1.3245.

Jay, J. M. (2001). Modern food microbiology (6th ed.). Gaithersburg: Aspen Publishers.

Kochanski, S., Pierozan, M. K., Mossi, A. J., Treichel, H., Cansian, R. L., Guilseni, C. P., \& Toniazzo, G. (2009). Avaliação das condições microbiológicas de uma unidade de alimentação e nutrição. Alimentos e Nutrição, 20(4), 663-668.

Malorny, B., Tassios, P. T., Rådström, P., Cook, N., Wagner, M., \& Hoorfar, J. (2003). Standardization of diagnostic PCR for the detection of foodborne pathogens. International Journal of Food Microbiology, 83(1), 39-48. http://dx.doi.org/10.1016/S0168-1605(02)00322-7. PMid:12672591.

Mohapatra, B. R., Broersma, K., \& Mazumder, A. (2007). Comparison of the five rep-PCR genomic fingerprinting methods for differentiation of fecal Escherichia coli from humans, poultry and wild birds. FEMS Microbiology Letters, 277(1), 98-106. http://dx.doi.org/10.1111/j.15746968.2007.00948.x. PMid:17986090.

Neves, M. C., Rossi, O. D. Jr., Alves, E. C. C., \& Lemos, M. V. F. (2007). Detecção de genes de resistência antimicrobiana em cromossomos e plasmídeos de Staphylococcus spp. Arquivos do Instituto Biológico, 74(3), 207-213.

Sambrook, J., \& Russel, D. W. (2001). Molecular cloning: a laboratory manual (3rd ed.). New York: Cold Spring Harbor Laboratory Press.

Serafim, A. L. (2010). Avaliação dos procedimentos de boas práticas na área de alimentos e bebidas em hotéis (Dissertação de mestrado). Universidade Federal de Santa Maria, Santa Maria.

Silva, J. E. A. (2008). Manual de controle higiênico sanitário em serviços de alimentação (6. ed.). São Paulo: Varela.

Silva, N., Junqueira, V. C. A., \& Silveira, N. F. A. (2001). Manual de métodos de análise microbiológica de alimentos. São Paulo: Varela.

Versalovic, J., Schneider, M., Bruijn, F. J., \& Lupski, J. R. (1994). Genomic fingerprinting of bacteria with repetitive sequencebased polymerase chain reaction. Methods in Molecular and Cellular Biology, 5, 25-40.

Zambiazi, S., \& Martins, A. H. (2010). Condições de armazenamento em restaurantes comerciais na cidade de Cascável, PR. Higiene Alimentar, 24(180), 36-42. 